\section{NIH: in line with expectations}

Washington. The 4.1 per cent budget increase being requested by President Clinton for the National Institutes of Health (NIH) in 1996 represents an increase that would give the NIH about $\$ 11.8$ billion to spend next year. Increases for individuals institutes ranging from a little below 3 per cent for some, to nearly 5.5 per cent for the Office of AIDS Research.

Overall, the NIH's proposed budget increase is a little below the Department of Commerce's predicted increase ( 4.3 per cent) in the cost of doing biomedical research in 1996. "It's disappointing," says Sam Silverstein, president of the Federation of American Societies for Experimental Biology (FASEB).

But the budget request is larger than the general rate of inflation, and roughly the amount that most observers expected. Most of the money that the NIH spends on research will, as usual, be awarded to unsolicited grants selected through peer review. In addition - and providing that the new Congress raises no objections - extra money will as last year also be directed into research on HIV and AIDS, and towards improving the health of women and minorities.

A new area for targeted research, championed by Harold Varmus, the director of the $\mathrm{NIH}$, will be preventitive research in gene therapy research. funds for instrumentation. brain disorders. Other targeted areas for funding will be environmental cancer and

Although observers say that are not surprised by the president's request, it falls far short of the 15 per cent increase that internal staff at the NIH estimate is needed to fund one third of grant proposals - at present, only 25 per cent are funded - and to provide the necessary buildings and equipment. But the NIH was not asking for this figure.

Such figures go some way to explaining a call by FASEB last year to increase the NIH's budget by 10 per cent. A staff member says that this percentage was based on an assessment of the need to increase the percentage of research proposals being funded, to expand training and to provide more

Given this call from FASEB, Silverstein's view that the current budget is a missed opportunity for the NIH is not entirely surprising. "At a time when the president is saying the country should invest, this budget is not an investment for the NIH, but holding the line," says Silverstein. For many, however, the budget was as much as could be expected in the circumstances -- andFASEB has several months in which to lobby Congress to increase the president's request.

Helen Gavaghan

\section{NASA: new starts despite tough year}

Washington. Although its budget request for next year of $\$ 14.36$ billion is $\$ 200 \mathrm{mil}$ lion less than this year's allocation, the National Aeronautics and Space Administration (NASA) intends to fund modest new initiatives in space science and technology, as well as a new reusable rocket programme (see Nature 373, 180; 1995).

The agency is seeking $\$ 6$ billion for its science, aeronautics and technology account, about the same level as in the current year. Funding for the space shuttle and space station programmes remains virtually constant, at $\$ 5.5$ billion.

The agency's budget request includes money that would allow it to begin work on two infrared astronomy missions that have long been on the drawing board: $\$ 15$ million for the Space Infrared Telescope Facility (SIRTF), and $\$ 49$ million for the Stratospheric Observatory for Infrared Astronomy (SOFIA). It also includes $\$ 50 \mathrm{mil}$ lion to develop a second spacecraft in the Mars Surveyor series, to be launched in 1998. The potential contractors for the Mars orbiter/lander will be chosen this spring.

The Discovery line of small planetary missions is requesting an additional $\$ 36$ million to begin work on at least one new mission to follow the Mars Pathfinder and Near Earth Asteroid Rendezvous (NEAR) missions already in development. NASA expects to make a selection from a list of candidate missions later this month. able Launch Vehicle programme, the agency is also asking for $\$ 30$ million to kick off what Administrator Daniel Goldin calls a "revolutionary" new technology development effort, called New Millennium. This aims at reducing both the cost and weight of current science spacecraft by a factor of ten.

The first demonstration mission, which would probably fly a miniaturized science payload to a nearby target such as an asteroid, could be launched as early as 1997. Goldin expects New Millennium to run as a continuing technology development effort, costing approximately $\$ 50$ million a year.

Funding for these new initiatives is being offset by general savings in operations, and by the reduced budgetary needs of the Cassini Saturn mission as it approaches its 1997 launch. There is, however, a wild card.

Money for the proposed Gravity-Probe $\mathrm{B}$ mission, designed to test Einstein's Theory of Relativity, is not included in NASA's 1996 budget request, as this awaits a recommendation by the National Academy of Sciences this summer on whether to proceed with the project. If the answer is yes, NASA will have to find $\$ 51$ million in a tight budget to pay for it next year.

Tony Reichhardt
In addition to $\$ 159$ million for the Reus-
Other highlights

Department of Interior: The 1996 request is for \$7.564 billion, \$215 million higher than last year. The administration is proposing slight raises for both the US Geological Survey (\$586 million, up \$15 million from 1995) and the National Biological Service (\$173 million, up \$6 million). The implication is that if either of these agencies are to be killed this year, Congress will have to do it.

The USGS request includes additional money for digital mapping, earthquake preparedness, seafloor mapping, and data collection and reporting under the $\mathrm{Na}$ tional Water Quality Assessment programme. The survey plans to save $\$ 4.6$ million by closing 54 water resources research institutes around the country.

Environmental Protection Agency: EPA is seeking $\$ 7.4$ billion in next year's budget, $\$ 138$ million more than it received in 1995. The agency's Office of Research and Development wants an increase of $\$ 84$ million on last year, increasing its budget to $\$ 630$ million although some of that rise is due to research funds being reclassified from elsewhere in the agency.

The agency is also asking Congress to approve spending an extra \$42 million on its recently expanded programme of external research grants, and \$5 million for more graduate student fellowships.

Department of Defense: Cuts of almost $\$ 1$ billion are being proposed from the $\$ 35$ billion which the Department of Defense spends on the development and test of military equipment, and which the US government classifies as "research and development." But the department wants to spend $\$ 1.2$ billion - the same as last year - on its university research, even though this lacks direct military application, and has come under attack from defence hawks in Congress.

Department of Commerce: The National Institute of Standards and Technology (NIST) continues to pursue the rapid expansion of its industrial technology programmes (SeeNature 373, 374; 1995). The NIST budget would rise from $\$ 854$ million to $\$ 1.023$ billion, with the Advanced Technology Programme (ATP) growing from $\$ 430$ million to $\$ 490$ million.

This is half the growth rate which the Clinton administration had previously advocated, but is still unlikely to appease Republican opponents of programme. The budget also proposes significant expansions in the Manufacturing Extension Partnership, and in NIST's intramural research programme. C. M. \& T. R. 